DOI 10.18551/rjoas.2021-11.10

\title{
GUIDANCE AND FOOD NEEDS IN KUTAI KARTANEGARA REGENCY WELCOMING THE NEW NATIONAL CAPITAL IN INDONESIA
}

\author{
Raden Ince ${ }^{\star}$, Thamrin, Dwijatenaya Ida Bagus Made Agung, Prayogi Erwin \\ Faculty of Agriculture, University of Kutai Kartanegara, East Kalimantan, Indonesia \\ *E-mail: inceraden@unikarta.ac.id
}

\begin{abstract}
Food is a basic human need. The 1945 State Constitution of the Republic of Indonesia stipulated that the state guarantees the right to food. This research aims to inform the guidance and food needs of Kutai Kertanegara Regency to welcome the New National Capital of Indonesia in East Kalimantan. A method used in this research was descriptive analysis. The data on the Guidance of food supply was presented in the form of tables, pictures, and graphs. Food needs used projections based on the number of population and food needs per commodity per capita per year. The results showed that the potential for the Guidance of food supply in Kutai Kartanegara Regency varied, originating from rice (lowland rice and hill rice), secondary crops, horticulture, animal husbandries such as ruminants and poultry, and capture fisheries and aquaculture. The average growth of the Kutai Kertanegara population was 2, 18 percent per year. Food needs will continue to increase along with population growth. Kutai Kertanegara's population in 2021 was approximately 820.722 people. The population mobilization plan after the National Capital (NC) estimated that the Kutai Kertanegara population in 2024 will reach 5,676,392 people, and if 25\% live in Kutai Kartanegara, it will be 1,419,098 people. Based on the analysis results of rice needs projection in 2024, before the NC, it is approximately 77.931 tons, and after NC, it attains 505.199 tons. In addition, the need for beef before NC is 2.329 tons, and after NC, it will be 15.099 tons. The need for poultry meat before NC is approximately 6,690 tons, and after NC, it reaches 43,368 tons, the need for eggs before NC is estimated at 6,042 tons and after NC, it attains 39,110 tons. The need for fish before NC is approximately 63,045 tons, and after NC, it attains 408,700 tons.
\end{abstract}

\section{KEY WORDS}

Guidance, needs, food, Kutai Kertanegara.

Agriculture is the leading sector that must be developed by the government of Indonesia, particularly in Kutai Kertanegara, because it is associated with meeting the food needs of the community. Food is the primary basic need for humans that must be met at all times. Food needs are a human right whose fulfillment is guaranteed by the 1945 Constitution of the Republic of Indonesia and specifically regulated in Law Number 18 of 2012 concerning Food. Also, foods have a significant position because it is closely associated with politics, economics, social and culture. In addition to meat and eggs, most of the population's staple food comes from cereals, consisting of rice, corn, and flour, and the largest staple food of the population is rice. Therefore, food security in Indonesia is significant to maintain political, economic, social, and cultural stability.

The provision of food as regulated in Law Number 18 of 2012 is carried out to meet basic human needs that provide benefits in a fair, equitable, and sustainable manner. Food shortages can create economic instability, endanger national stability, and lead to social and political turmoil. Smaller availability of foods than the needs has been feared since 1798 when Thomas Malthus warned that the number of people increased exponentially, while efforts to increase food supplies could only increase arithmetically. History recorded various local famine events, which sometimes spread to national famine and hit numerous countries.

Fulfillment of food needs and maintaining foods security is becoming more important for Indonesia because of the large number of its population with large geographic scope coverage. Indonesia requires a large number of foods and foods distribution for the 
community. It must meet consumption or logistic criteria, including easily accessible by every person, and the foods must be available for the community day by day. Various problems then arise to meet food needs. Those are the commodity production that is vulnerable to climate change, the characteristics of food that are easily damaged, limited land for farmers' production, inadequate agricultural supporting facilities and infrastructure, weak harvest and post-harvest handling, a distribution which are limited and expensive, too long trade chains that result in high price differences. These indeed require intervention from the central and regional governments in realizing food security policies, namely policies concerning the balance between aspects of food production and demand.

From the principle of food fulfillment and the various problems in fulfilling food, it raises another big challenge for East Kalimantan in general and Kutai Kartanegara Regency in particular. It is the stipulation of East Kalimantan as the new National Capital (NC), where the central point is the National Capital. The new National Capital (NC) is located in 2 (two) regions, namely Kutai Kartanegara Regency (KUKAR) and North Penajam Paser Regency.

The big challenge regarding food fulfillment is the potential entry of State Civil Apparatus and their families' residents from various ministries or agencies in Indonesia, which is predicted to reach 3 million people to East Kalimantan. Based on the results of the 2015 Supas entitled Indonesia Population Projection 2015-2045, it is projected that East Kalimantan's population growth every five years will increase by an average of $4.41 \%$. In 2020, the population of East Kalimantan is predicted to reach 3.6 million people. Five years later, it increases by $5.86 \%$ to 3.9 million people. By 2030, the population will increase by $5.02 \%$ to 4 million people. Until 2045 the population of East Kalimantan is projected to increase by $5.8 \%$ from the previous five years. In 2045 the population of East Kalimantan will be 4.4 million people. Based on this population projection data, supplemented with the potential for population growth due to the determination of $\mathrm{NC}$ of 3 million people, the total population of East Kalimantan in 2020-2045 is estimated to reach 6.6-7.4 million people.

To realize food security in term of the National Capital (NC) by concerning to the balance between aspects of food needs and production for 6.6-7.4 million people, this research aims to inform the guidance and food needs of the Kutai Kartanegara Regency in welcoming the new National Capital of Indonesia in East Kalimantan.

\section{METHODS OF RESEARCH}

Administratively, the research location was in the Kutai Kartanegara Regency, covering 18 sub-districts. The map of the research area is according to Figure 1 . The research period was carried out for three (3) months from October to December 2020.

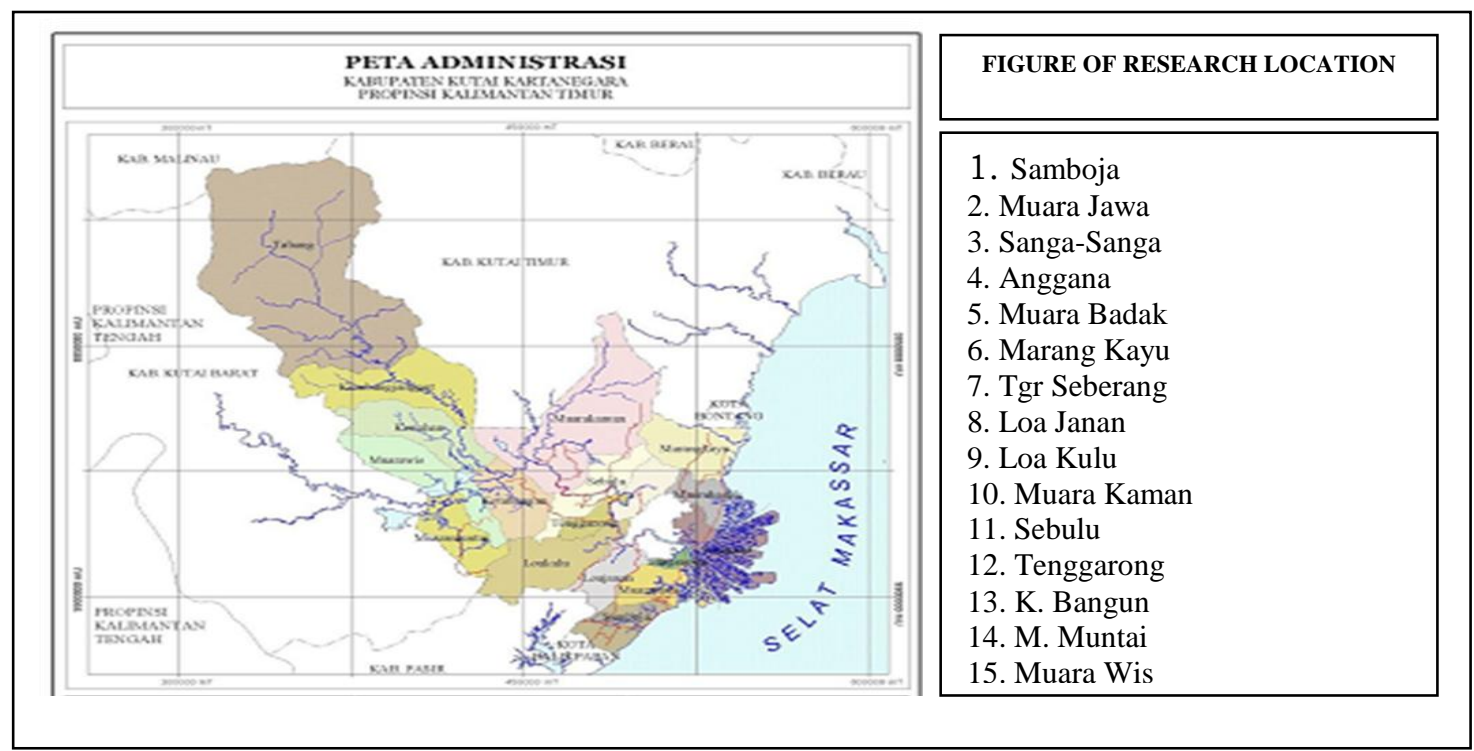

Figure 1 - Research location of Guidance and Food Needs towards the New National Capital Region 
The data collected in this research were primary and secondary data, which was relevant to the aims of this research. The data was collected using the triangulation technique. It is a data collection combination between library researches, depth interview, and assisted by questionnaires and fieldwork research.

The descriptive analysis method was used to describe the characteristic of a situation when the research was carried out and to see the causes of a particular phenomenon that was existed in the research location (Sugiyono, 2015). The guidance of the provision of foodstuffs was described in the form of tables, graphs, pictures, or diagrams. Food needs used projections based on population and food needs per commodity per capita per year.

\section{RESULTS AND DISCUSSION}

Guidance of foodstuffs in Kutai Kertanegara varies. The rice commodity planted in the lowland rice of 33.402 ha produces 138,88 tons rice, and hill rice of 3.524 ha with production results of 9.811 tons dominated planted area in 2019. It shows that the basic food needs of the Kutai Kertanegara community are still dominated by rice. Furthermore, corn is the second largest commodity after lowland rice with a planting area of 4.925 ha and produces 20.782 tons. It is caused by a corn revolution program established by the district government of Kutai Kertanegara. The planted area of cassava and sweet potato commodities are 834 ha and 392 ha each. These commodities are prepared by the district government as a food substitute for rice because it is also a source of carbohydrates. Meanwhile, the planted area of peanut is 279 ha, and soya bean is 25 ha. Based on table 1, it shows that the productivity of lowland rice is 4.2 tons ha $^{-1}$ while hill rice is 2.8 tons $\mathrm{h}^{-1}$. It is still higher than the productivity of lowland rice and hill rice at the provincial level of East Kalimantan, which are 3.64 tons $\mathrm{ha}^{-1}$ and 2.5 tons $\mathrm{ha}^{-1}$, respectively. On the other hand, the productivity of corn, cassava, sweet potatoes, peanuts, and soybeans is still low compared to the productivity of these commodities at the provincial and national levels of East Kalimantan.

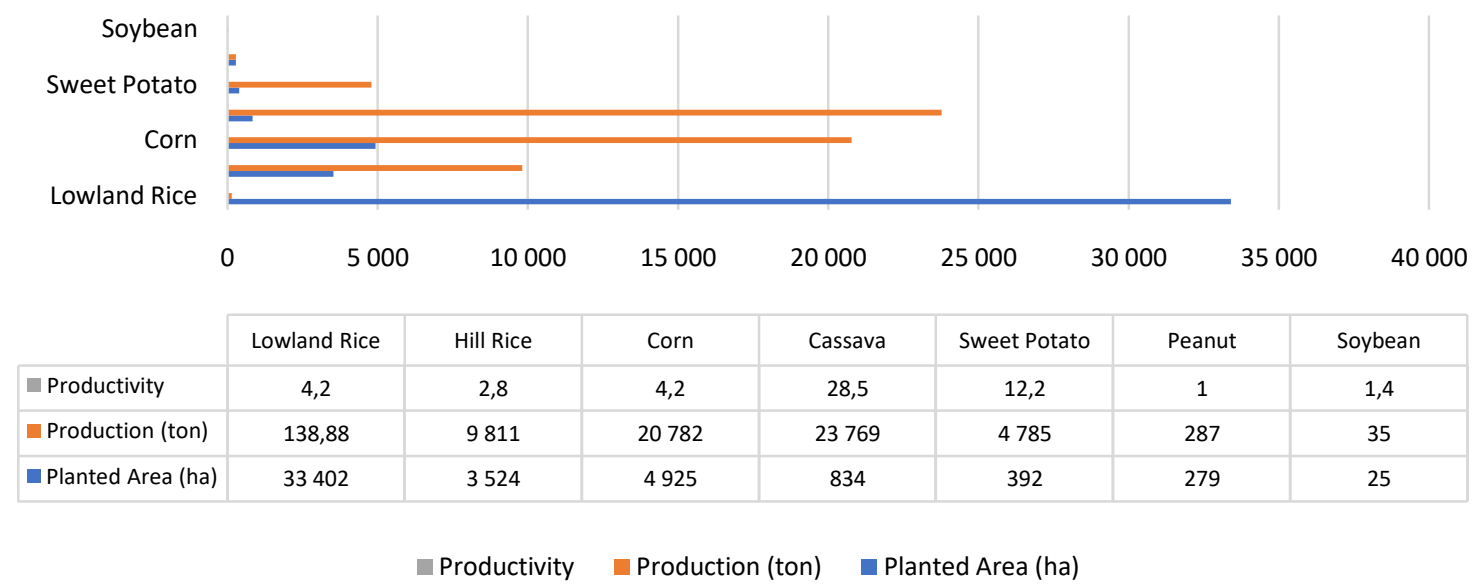

Figure 1 - Planted Production Area and Productivity of Food Crops in Kutai Kartanegara Regency in 2019. Source: Department of Agriculture and Livestock, Kutai Kartanegara Regency, 2020

Horticultural commodities of tomatoes, chilies, long beans, eggplant, and cucumbers are the 5 (five) largest commodities grown in Kutai Kartanegara. Figure 2 shows that the planted area of chili (807 ha), long beans (660 ha), cucumber (523 ha), eggplant (509 ha), and tomato (396 ha). The guidance of these horticultural commodities provides an alternative for consumers to obtain sources of vitamins and minerals. Chili commodity has the widest planting area. This condition indicates that the need for chili is significantly needed by the Kutai Kartanegara community. The production and productivity of these horticultural commodities need to be increased in order to meet the needs of the new National Capital in East Kalimantan. 


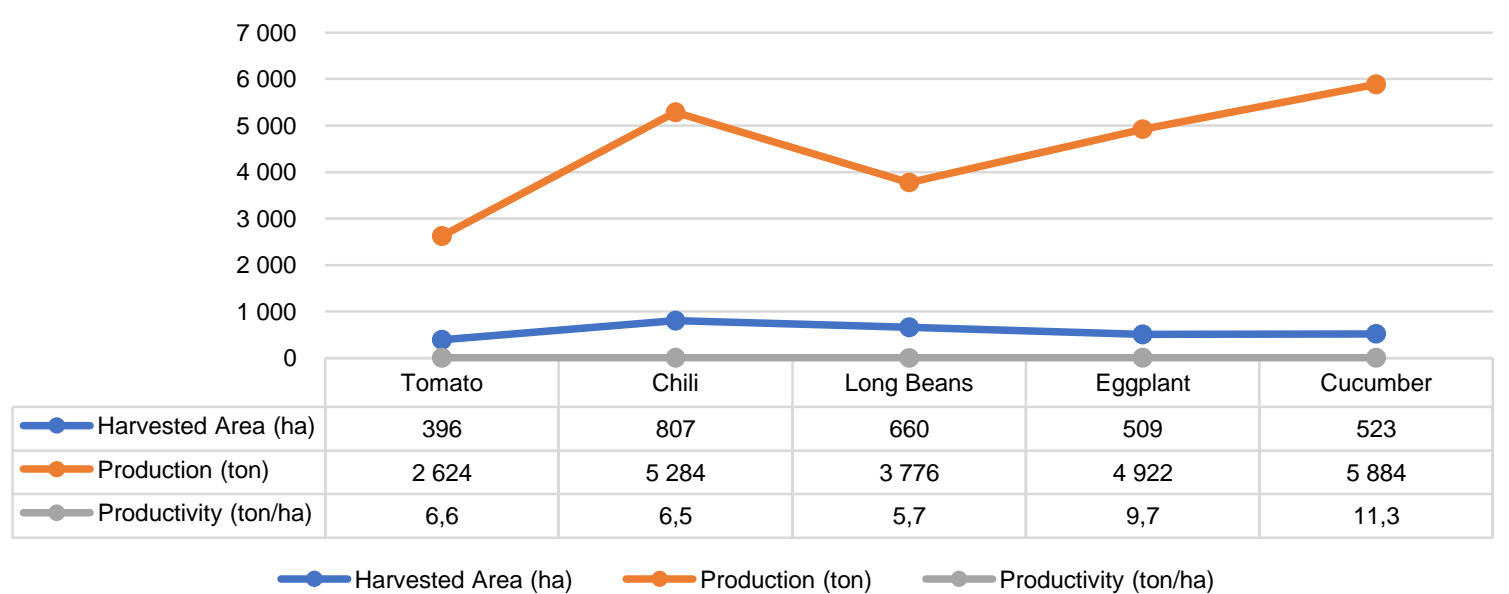

Figure 2 - Harvested area of production and productivity of Horticultural Crops in Kutai Kartanegara Regency in 2019 Source: The Central Bureau of Statistics of Kuta Kartanegara Regency, 2020

The Kutai Kartanegara region has 27,509 cattle livestock, this figure is still far dominantly raised by breeders compared to 2,394 buffaloes, 11,058 goats, and 2,394 pigs. This type and number of livestock support the production of beef with the highest production of 527 tons, 27 tons of pigs, 22 tons of goats, and 14 tons of buffaloes.
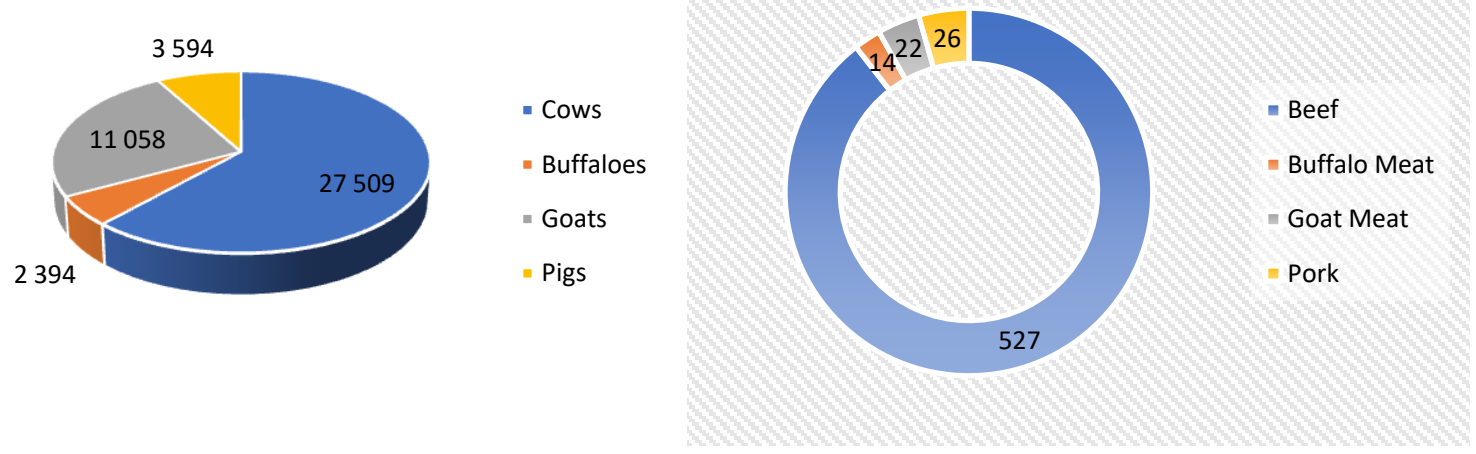

Figure 3 - The Population and Production of Ruminant Meat in Kutai Kartanegara Regency in 2019 (Source: The Central Bureau of Statistics of Kutai Kartanegara Regency, 2020)

The population of local chickens are 398,951 which are the largest population of poultry in Kutai Kartanegara Regency compared to the population of 180,201 laying hens, 14,141 broilers, and 66,602 ducks. This poultry population contributes to the supply of poultry meat needs. Poultry production of 437 tons of free-range chicken is the highest compared to other types of poultry. This is relevant to the number of populations raised by farmers.

The production of local chicken eggs decreased from 2015 to 2019. In 2019, the production was very low at 274.48 tons compared to 2015 which reached 2,455.52 tons (a production decreased of almost 10 times). For broilers, there were fluctuations in egg production which increased in production in 2015-2017 and decreased in 2017-2019. The lowest production occurred in 2019 for the last 5 years. This is the same as local chicken egg production. This is inversely proportional to the laying hens, which continue to increase in egg production from 2015-2019.

Production of capture fisheries and aquaculture as suppliers of fish consumers in Kutai Kartanegara Regency. The results of cage cultivation are 62,536 tons and 47,472 tons of ponds are the largest supply of fish needs in Kutai Kartanegara Regency. Meanwhile, the 
results of fishing in sea waters, and public waters yielded 42,203 tons and 34,582 tons, respectively. The high production of cages is due to the existence of the Mahakam river and several lakes as well as the existence of ex-mining voids used for cage cultivation. Meanwhile, the high yield of fish from ponds is due to the Mahakam delta which is currently widely used by the community for fishery business.

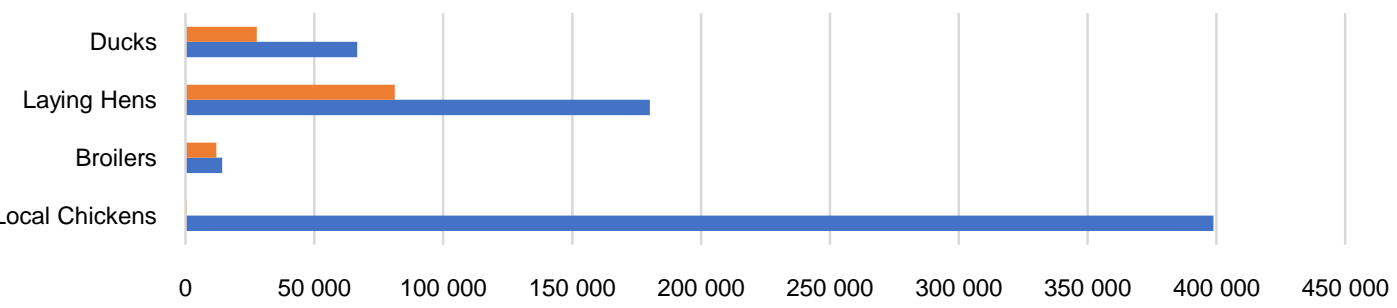

\begin{tabular}{|l|c|c|c|c|}
\cline { 2 - 5 } \multicolumn{1}{c|}{} & Local Chickens & Broilers & Laying Hens & Ducks \\
\hline - Meat Production (ton) & 437 & 11836 & 81094 & 27648 \\
\hline - Populations (number) & 398951 & 14141 & 180201 & 66602 \\
\hline
\end{tabular}

Meat Production (ton) $\quad$ Populations (number)

Figure 4 - Meat Production and Poultry Livestock Population in Kutai Kartanegara Regency in 2019 (Source: The Central Bureau of Statistics of Kuta Kartanegara Regency, 2020)

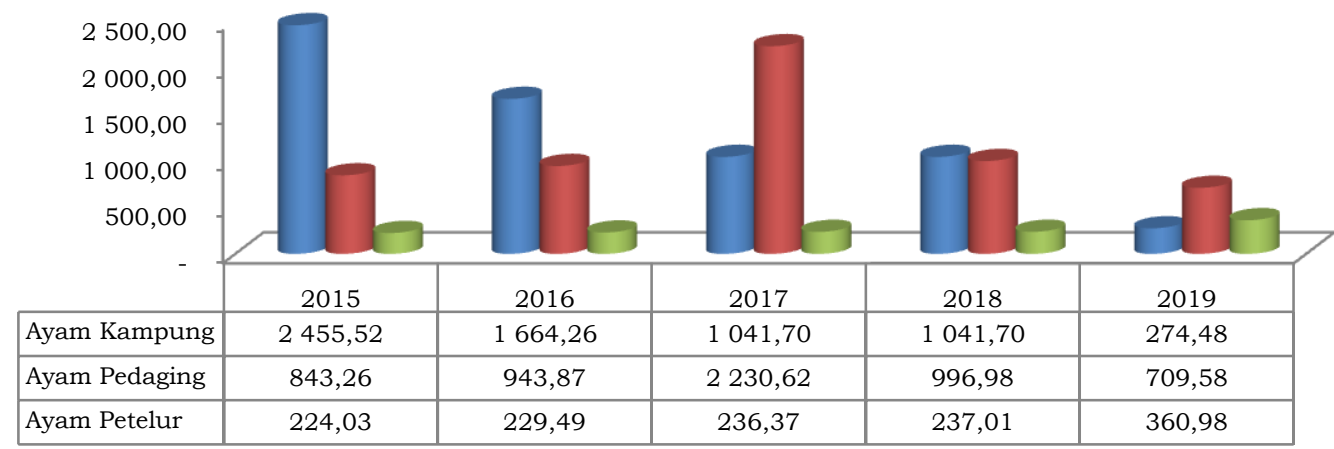

Figure 5 - The Development of Poultry Egg Production (tons) in Kutai Kartanegara Regency in 2019 (Source: The Central Bureau of Statistics of Kuta Kartanegara Regency from 2016 to 2020)

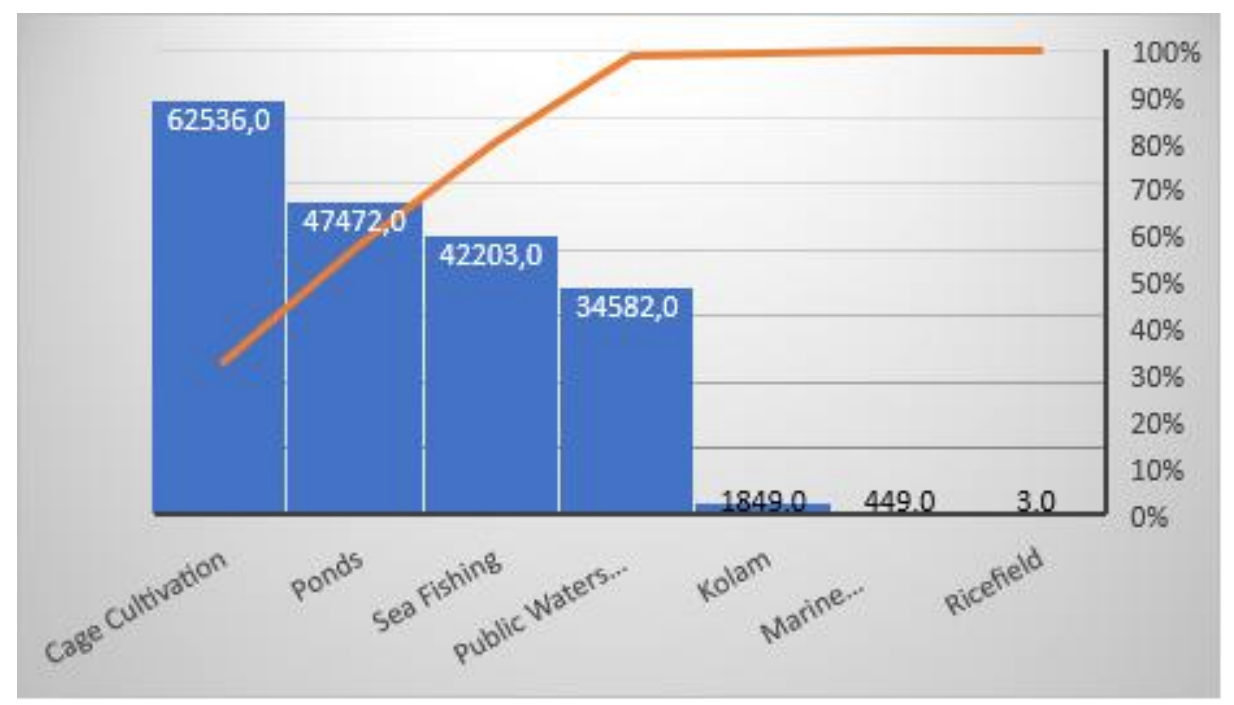

Figure 6 - The Capture Fisheries Production and Cultivation in the Kutai Kartanegara Regency in 2019 (Source: The Central Bureau of Statistics of Kutai Kartanegara Regency, 2020) 
Based on the current conditions, the average needs per capita of Indonesians nationally on the guidance of food is presented in Figure 7. Rice demand are $89 \mathrm{~kg}$ per capita annually; beef $2.66 \mathrm{~kg} ; 7.64 \mathrm{~kg}$ of poultry meat; $6.89 \mathrm{~kg}$ eggs; and fish meat $72 \mathrm{~kg}$ per capita annually.

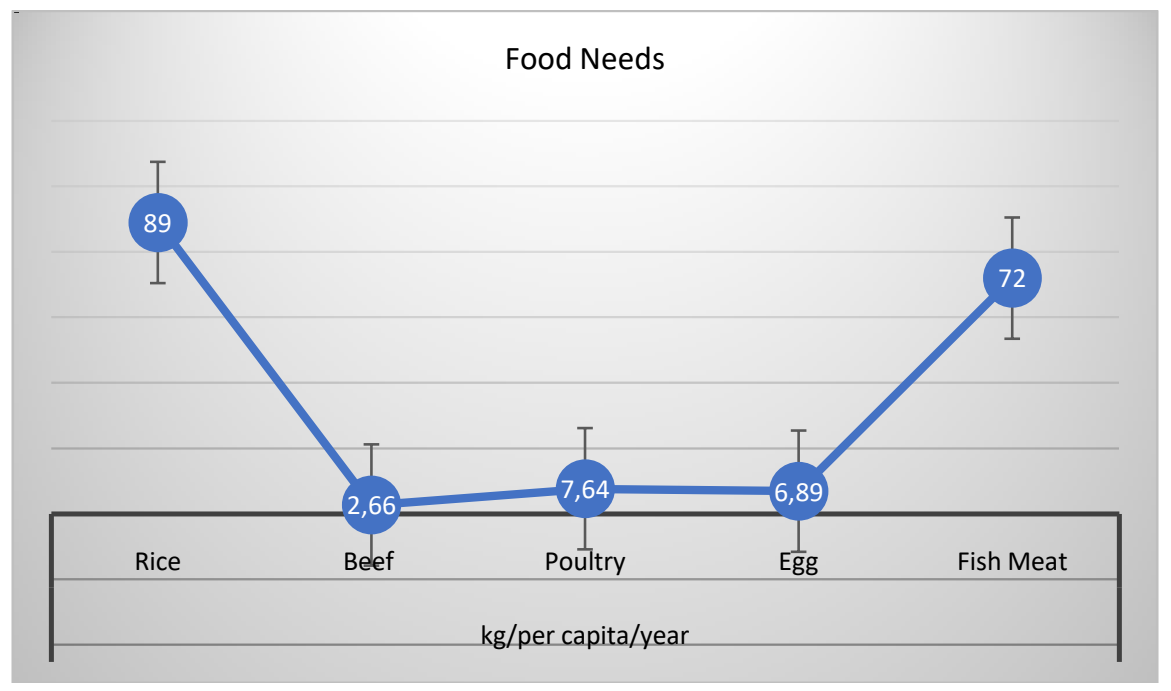

Figure 7 - The needs of the guidance of food $\mathrm{kg} /$ per capita per year

Food demand specifically for rice in the Kutai Kartanegara Regency can be calculated based on the annual rice consumption of the population per capita. By referring to the annual rice consumption of the population per capita nationally, the population of the Kutai Kartanegara Regency consume approximately 89 kilograms of rice per capita per year. With a population approximately 803,260 people, it means that the needs for rice is roughly $71,490,183$ kilograms (71,490 tons) per year. Based on the data above, it can be interpreted that the actual rice production in Kutai Kartanegara Regency is experiencing a sufficient surplus, but it is concerned that the area of agricultural land is increasingly decreased due to the conversion of agricultural land to other sectors.

Table 1 - The Projection between Food Needs and Population in Kutai Kartanegara before and after the NC in 2024

\begin{tabular}{|c|c|c|c|c|c|}
\hline \multirow{2}{*}{ NO } & \multirow{2}{*}{ Foodstuffs } & \multicolumn{4}{|c|}{ Food Needs (person) } \\
\cline { 3 - 6 } & & \multirow{2}{*}{ Per capita (kg/year) } & \multicolumn{3}{|c|}{ Kukar (ton) } \\
\cline { 3 - 6 } & & & \multirow{2}{*}{ Before NC } & \multicolumn{2}{|c|}{ After NC } \\
\cline { 3 - 6 } & & 89 & 77.931 & 505.199 & 126.300 \\
\hline 1 & Rice & 2,66 & 2.329 & 15.099 & 3.775 \\
\hline 2 & Beef & 7,64 & 6.690 & 43.368 & 10.842 \\
\hline 3 & Chicken & 6,89 & 6.042 & 39.110 & 9.778 \\
\hline 4 & Egg & 72,0 & 63.045 & 408.700 & 102.175 \\
\hline 5 & Fish & &
\end{tabular}

Note: Kukar population in 2021: 820,772 people; in 2024, if all of NC populations living in Kukar, the total populations of NC will be 5.676 .392 people, whereas if $25 \%$ of the populations live in Kukar, it will be 1,419,098 people. Source: Data processed in 2020.

By 2021 to 2024, the rice needs projection for the population in the Kutai Kartanegara Regency before the NC by referring to the average population growth rate of 2.18 percent, it is estimated that in 2021 the need for foodstuffs before and after the NC will increase.

\section{CONCLUSION}

The potential for the guidance of food supply in the Kutai Kartanegara Regency varies from rice (lowland rice and hill rice), secondary crops, horticulture, animal husbandry in the form of ruminants, poultry, eggs, and capture fisheries and aquaculture. 
The average need per capita per year of Indonesians nationally for the guidance of food of rice is $89 \mathrm{~kg}$ per capita per year; beef $2.66 \mathrm{~kg} ; 7.64 \mathrm{~kg}$ of poultry meat; $6.89 \mathrm{~kg}$ eggs; and fish meat $72 \mathrm{~kg}$ per capita per year.

The rice needs projection in 2024 before the NC reach approximately 77.931 tons and after the NC reach 505.199 tons, the needs for beef before the NC approximately 2.329 tons and reach 15.099 tons after the NC, the needs for poultry meat before the NC approximately 6.690 tons and reach 43.368 ton after the NC, the needs for egg before the NC approximately 6.042 tons and reach 39.110 tons after the NC, the needs for fish meat before the NC approximately 63.045 tons and reach 408.700 tons after the NC.

\section{REFERENCES}

1. [BAPPEDA] Badan Perencanaan Pembangunan Daerah Kabupaten Kutai Kartanegara. 2018. Master Plan for Agricultural Development for Kutai Kartanegara Regency for 2019 $-2025$.

2. BPS-Statistict Indonesia. 2018. Indonesia Populaton Projection 2015-2015. Result of SUPAS 2015. Jakarta.

3. BPS [Badan Pusat Statistik) Kabupaten Kutai Kartanegara. 2020. Kutai Kartanegara in Figures for 2020. BPS Kukar. Tenggarong.

4. [DIPERTANAK] Dinas Pertanian dan Peternakan Kabupaten Kutai Kartanegara. 2020. Rekap Kelembagaan Pelaku Utama per BPP Kabupaten Kutai Kartanegara, Provinsi Kalimantan Timur. Dipertanak Kukar. 2020.

5. [DIRJEN] Direktorat Jenderal Perikanan Budidaya Kementerian Kelautan Dan Perikanan. 2018. Budidaya Ikan Sistem Minapadi. Dirjen Perikanan Budidaya. Kementerian Kelautan dan Perikanan. Jakarta.

6. Evy, R, Endang Mujiutami, dan K Sujono. 2001. Usaha Perikanan di Indonesia, Mutiara Sumber Widja, Jakarta.

7. Yayusofiana. 2018. Dampak Kebijakan Impor Terhadap Ketahanan Pangan. Program Studi IImu Pemerintahan. Universitas Yogyakarta. Yogyakarta.

8. Ritung. 2. 2010. Lahan Sawah Dan Kecukupan Produksi Bahan Pangan (Rice Field Necessity to Sufficient Production of Food Material). Jurnal Sumberdaya Lahan Vol. 4 No. 1, Juli 2010. Balai Besar Litbang Sumberdaya Lahan Pertanian. Bogor.

9. Saragih, J. R. (2015). Perencanaan Wilayah dan Pengembangan Ekonomi Lokal Berbasis Pertanian. Pustaka Pelajar. Yogyakarta.

10. Sugiyono.2015.Metode Penelitian Manajemen.Cetakan Keempat. Bandung: AlfaBeta.

11. Undang-Undang Dasar. 1945. Undang-Undang Negara Republik Indonesia.

12. Undang-Undang No 18 tahun 2012 tentang Pangan. 